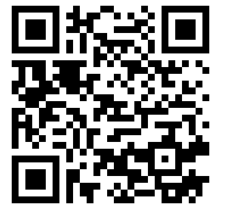

Submitted: 2019-09-29

Accepted : 2019-12-02
Journal An-Nafs: Kajian Penelitian Psikologi https://ejournal.iai-tribakti.ac.id/index.php/psikologi e-ISSN: 2549-6166 p-ISSN: 2528-0600 DOI: $10.33367 /$ psi.v5i1.928

Revised : 2019-10-17 Published: 2020-06-01

\title{
PEMAHAMAN UNDANG-UNDANG PERKAWINAN TERHADAP PENUNDAAN PERKAWINAN USIA DINI DI INDONESIA
}

\author{
Agoes Dariyo', Mia Hadiati², R. Rahaditya ${ }^{3}$ \\ 1agoesd@fpsi.untar.ac.id, ${ }^{2}$ miahadiati@fh.untar.ac.id, ${ }^{3}$ rahaditya@mku.untar.ac.id \\ Universitas Tarumanagara Jakarta
}

\begin{abstract}
Early age marriages have become widely reported through various media both print and electronic media, because early marriage is one of the causes of divorce in Indonesia. Divorce due to early marriage raises social problems in the community, such as high dropout rates for students, poverty, crime. The emergence of early marriage is caused by the low awareness of adolescents to understand Law number 1 of 1974 concerning marriage. This study discusses the understanding of law number 1 of 1974 concerning marriages which plays a role for adolescents to postpone early marriage in Indonesia. This research method uses a quantitative approach, involving 213 adolescent subjects with an age range of 17-22 years. Retrieval of data using a questionnaire that is the attitude of understanding marriage law, life satisfaction, resilience, and delaying early marriage. Analysis of research data using Spearman RHO correlation and non-linear regression. The results showed that the attitude of understanding marital law plays a role in delaying early marriage in adolescents in Indonesia.
\end{abstract}

Keywords: Marital law, Early-age marriage

\begin{abstract}
Abstrak
Perkawinan usia dini telah menjadi pemberitaan luas melalui berbagai media baik media cetak maupun media elektronik, sebab perkawinan usia dini menjadi salah satu penyebab perceraian di Indonesia. Perceraian akibat perkawinan usia dini memunculkan masalahmasalah sosial di masyarakat, seperti tingginya angka drop out siswa, kemiskinan, kriminalitas. Munculnya perkawinan usia dini disebabkan oleh rendahnya kesadaran remaja untuk memahami undang-undang nomor 1 tahun 1974 tentang perkawinan. Penelitian ini membahas mengenai pemahaman undang-undang nomor 1 tahun 1974 tentang perkawinan berperan bagi remaja untuk melakukan penundaan perkawinan usia dini di Indonesia. Metode penelitian ini mengunakan pendekatan kuantitatif, melibatkan subjek remaja berjumlah 213 orang dengan rentang usia 17-22 tahun. Pengambilan data dengan menggunakan kuosioner yaitu sikap pemahaman hukum perkawinan, kepuasan hidup, resiliensi dan penundaan perkawinan usia dini. Analisis data penelitian dengan menggunakan korelasi spearman rho dan regresi non-linear. Hasil penelitian menunjukkan bahwa sikap pemahaman hukum perkawinan berperan dalam penundaan perkawinan usia dini pada remaja di Indonesia.
\end{abstract}

Kata Kunci: Hukum perkawinan, Pernikahan dini 
Agoes Dariyo dkk | Pemahaman Undang-Undang Perkawinan

\section{PENDAHULUAN}

Badan Pusat Statistik (2018) menyebutkan bahwa perceraian semakin meningkat secara tajam di Indonesia. Beberapa provinsi yang memiliki angka perceraian tertinggi di Indonesia antara lain Kalimantan Selatan, Sulawesi Barat, Sulawesi Selatan, DKI Jakarta, Jawa Barat, Jawa Tengah, dan Jawa Timur. Salah satu penyebab perceraian adalah banyaknya perkawinan usia dini yang dilakukan oleh remaja (Pranawati, 2018). Hal ini terjadi karena mereka sebagai remaja tidak memiliki kesadaran pemahaman terhadap undang-undang nomor 1 tahun 1974 tentang perkawinan (Djubaedah, 2019). Mereka menikah pada usia relatif muda, namun tak mampu mempertahankan mahligai perkawinan ketika menghadapi berbagai persoalan dalam rumah tangga. Mereka lebih memilih untuk bercerai daripada berupaya memperbaiki dan mempertahankan hubungan perkawinan. Sementara itu, perceraian sendiri akan berdampak buruk yang akan dirasakan oleh anak-anak dari keluarga bercerai, seperti kekhawatiran akan masa depan, drop out sekolah, kenakalan atau kriminalitas (Köppen dkk., 2018). Itulah sebabnya, undang-undang perkawinan harus disosialisasikan, diperkenalkan dan diajarkan kepada anak-anak dan atau remaja, agar mereka mampu mengambil keputusan menunda perkawinan usia dini, demi mencegah hal-hal yang tidak diinginkan di masa yang akan datang.

Undang-undang nomor 1 tahun 1974 tentang perkawinan menjadi dasar untuk bersikap, bertindak maupun berbuat segala sesuatu yang terkait dengan perkawinan bagi seluruh warga negara Indonesia (Ashsubli, 2015; Septiawan, 2017). Pengenalan, pengetahuan dan pemahaman yang benar mengenai undang-undang perkawinan memiliki peran penting bagi terbentuknya sikap dan perilaku positif yang terkait dengan perkawinan. Mereka akan menghargai perkawinan karena merupakan peristiwa yang suci, kudus atau sakral. Karena itu perkawinan harus dijalani secara serius dan berlaku seumur hidup, tidak boleh orang mempermainkan perkawinan. Jadi jangan sampai orang menjalani perkawinan, namun berakhir dengan perceraian (Wardani dkk., 2018). Perceraian bukan hanya dilarang oleh semua ajaran agama, tetapi juga berdampak buruk yang dirasakan oleh pasangan suami-istri yang bercerai maupun dampak psikologis yang dirasakan oleh anak-anak (Köppen dkk., 2018).

Penyusunan undang-undang nomor 1 tahun 1974 tentang perkawinan didasari oleh UUD 1945 Pasal 28 Undang-undang Dasar 1945 menegaskan bahwa setiap warga negara memiliki hak untuk melangsungkan perkawinan demi memperoleh keturunan. Selanjutnya, undang-undang perkawinan mengatur bahwa seorang laki-laki diperbolehkan untuk menikah pada usia 19 tahun, sedangkan seorang wanita boleh 
menikah pada usia 16 tahun. Namun demikian, sebenarnya usia 16-19 tahun masih tergolong remaja (Papalia dkk., 2012; Santrock, 2019). Remaja masih tergolong masa transisi yaitu peralihan dari masa anak-anak menuju masa dewasa. Sebagai masa transisi, maka remaja masih mengalami perubahan fisiologis, kognitif maupun psikososial (Papalia dkk., 2012; Santrock, 2019), agar mereka tumbuh kembang menjadi orang dewasa yang siap mandiri dan bertanggung-jawab di masyarakat (Berk \& Meyers, 2016).

Sebenarnya, mereka yang menikah pada usia 16-19 tahun tergolong sebagai perkawinan usia dini, bila hal ini tidak dicegah maka dikuatirkan angka perceraian akan tetap tinggi di negara Indonesia (Statistik, 2018). Karena itu, remaja perlu dibekali dengan pengetahuan mengenai undang-undang nomor 1 tahun 1974 tentang perkawinan. Pemahaman undang-undang perkawinan akan menumbuhkan sikap positif terhadap perkawinan. Perkawinan sebagai ikatan sah antara pasangan suami-istri yang dilandasi oleh keyakinan keagamaan untuk memperoleh keturunan. Karena itu, seseorang harus mempersiapkan diri sebaik-baiknya. Caranya dengan mewujudkan kepuasan dalam hidupnya (life-satisfaction) (Preisner dkk., 2018). Jika seseorang mampu mencapai kebahagiaan dalam hidupnya, maka ia sungguh-sungguh bisa menikmati, menghayati dan mensyukuri kehidupannya, sehingga ia tidak akan terburu-buru untuk menikah pada usia muda. Jadi dengan demikian, ia menunda usia pernikahannya sampai merasa siap untuk memasuki dan mempertahankan masa perkawinannya dengan baik (Karamat, 2016).

Jadi betapa pentingnya bagi seorang remaja untuk diperkenalkan mengenai undang-undang perkawinan. Dengan mempelajari, dan memahami undang-undang perkawinan tersebut, maka muncullah sikap positif dalam diri remaja terhadap undangundang perkawinan. Pemahaman yang benar mengenai undang-undang perkawinan akan mampu menumbuhkan ketangguhan (resiliensi) dalam hidupnya. Resiliensi adalah karakteristik pribadi yang ditandai dengan kemampuan untuk menghadapi situasi yang sulit (Fagan \& Palkovitz, 2007). Masa remaja itu dianggap sebagai masa yang sulit karena remaja dituntut untuk mampu menyesuaikan diri agar dapat menghadapi perubahanperubahan fisiologis, kognitif maupun psikosial (Papalia dkk., 2012; Santrock, 2019). Karena itu, karakteristik pribadi yang tangguh (resiliensi) diharapkan akan membuat seseorang berhasil mengatasi kesulitan-kesulitan dalam hidupnya. Demikian pula, orang yang tangguh akan mampu untuk menunda perkawinan agar tidak menikah pada usia dini.

Karena itu, dari berbagai pemaparan di atas maka dikemukakan rumusan masalah yaitu (1) bagaimana peran sikap pemahaman undang-undang nomor 1 tahun 1974 tentang perkawinan terhadap penundaan perkawinan usia dini pada remaja, 
bagaimana peran sikap pemahaman undang-undang nomor 1 tahun 1974 tentang perkawinan untuk dapat menumbuh-kembangkan kepuasan hidup pada remaja sehingga seorang remaja berupaya untuk melakukan penundaan perkawinan usia dini, (3) bagaimana peran sikap pemahaman undang-undang nomor 1 tahun 1974 tentang perkawinan dapat menumbuh-kembangkan resiliensi sehingga seorang remaja berupaya untuk melakukan penundaan perkawinan usia dini.

\section{METODE}

Metode penelitian ini menggunakan pendekatan kuantitatif yaitu suatu pendekatan penelitian yang menekankan pada analisis statistik terhadap data-data yang dikumpulkan selama pengambilan data di lapangan. Penelitian melibatkan subjek remaja akhir dengan rentang usia 17-22 tahun dan berjumlah sebanyak 213 orang yaitu laki-laki $(69=32,4 \%)$ dan perempuan $(144=67,6 \%)$. Subjek berasal dari suku tionghoa (138 orang $=64,8 \%)$, Jawa $(24=11,3 \%)$, Sunda $(14=6,6 \%)$, Batak $(10=4,7 \%)$, dan sisanya suku-suku bangsa lainnya (27 orang/12,6\%).

Pengambilan data dengan menggunakan kuosioner yaitu sikap hukum perkawinan, kepuasan hidup, resiliensi dan penundaan perkawinan usia dini. Kuesioner sikap terhadap undang-undang nomor 1 tahun 1974 tentang perkawinan (4 item) dan penundaan perkawinan usia dini (4 item) disusun oleh para peneliti. Kuesioner kepuasan hidup menggunakan kuesioner Ed Diener dan kuesioner resiliensi dari Wagnile versi singkat (14 item). Kuesioner dengan menggunakan skala Likert dan setiap item pernyataan terdiri dari 7 pilihan yaitu SS (sangat setuju), S (setuju), AS (Agak Setuju). N (Netral), ATS (Agak Tidak Setuju), TS (Tidak Setuju), STS (Sangat Tidak Setuju). Item yang positif (favourable) bergerak dari angka skor 7-1; sedangkan item yang negatif (unfavourable) bergerak dari angka skor 1-7. Adapun validitas dan reliabilitas alat ukur dapat diketahui pada tabel 1 di bawah ini.

Tabel.1. Validitas dan reliabilitas alat ukur (kuesioner)

\begin{tabular}{llccc}
\hline No & \multicolumn{1}{c}{ Variabel } & N Item & $\begin{array}{c}\text { Validitas } \\
\text { Corrected Item-Total } \\
\text { Correlation }\end{array}$ & $\begin{array}{c}\text { Reliabilitas } \\
\text { Cronbach's Alpha }\end{array}$ \\
\hline 1 & Sikap hukum perkawinan & 4 & $.352-.606$ & .669 \\
\hline 2 & Kepuasan Hidup & 5 & $.480-.760$ & .807 \\
\hline 3 & Resiliensi & 14 & $.323-.704$ & .875 \\
\hline 4 & Penundaan perkawinan usia dini & 4 & $.293-.497$ & .617 \\
\hline
\end{tabular}




\section{Uji asumsi}

Sebelum melakukan uji analisis data, maka terlebih dahulu dilakukan uji asumsi yaitu normalitas dan linearitas (Gozali, 2007; Nisfianoor, 2014). Hasil uji asumsi normalitas diketahui bahwa semua variabel tergolong berdistribusi tidak normal

Tabel.2. Uji asumsi normalitas

\begin{tabular}{clccc}
\hline No & \multicolumn{1}{c}{ Variabel } & Kolmogorov-Smirnov Test & & Keterangan \\
\hline 1 & $\begin{array}{l}\text { Sikap hukum } \\
\text { perkawinan }\end{array}$ & .019 & $\mathrm{P}<.05$ & Tidak normal \\
\hline 2 & Kepuasan Hidup & .002 & $\mathrm{P}<.05$ & Tidak normal \\
\hline 3 & Resiliensi & .000 & $\mathrm{P}<.05$ & Tidak normal \\
\hline 4 & $\begin{array}{l}\text { Penundaan } \\
\text { perkawinan usia dini }\end{array}$ & .000 & $\mathrm{P}<.05$ & Tidak normal \\
\hline
\end{tabular}

Melalui uji asumsi linearitas diketahui bahwa (1) data variabel sikap hukum perkawinan terhadap penundaan perkawinan usia dini tergolong linear $(p=.637, p>.05)$, (2) data variabel sikap hukum perkawinan terhadap kepuasan hidup tergolong linear ( $p=$ $.678, \mathrm{p}>$.05), (3) data variabel sikap hukum perkawinan terhadap resiliensi tergolong linear ( $\mathrm{p}=.063, \mathrm{p}>.05$ ). Selanjutnya, (4) data variabel kepuasan hidup terhadap penundaan perkawinan usia dini tergolong linear $(p=.877, p>.05)$, (5) data variabel resiliensi terhadap penundaan perkawinan usia dini tergolong linear $(p=.274, p>.05)$, serta (6) data variabel kepuasan hidup terhadap resiliensi tergolong tidak linear ( $p=.017$, $\mathrm{p}<.05)$

Tabel 3. Uji asumsi linearitas

\begin{tabular}{clcccc}
\hline \multirow{2}{*}{ No } & \multicolumn{1}{c}{ Variabel } & \multicolumn{4}{c}{ Linearitas } \\
\cline { 2 - 5 } & \multicolumn{1}{c}{1} & 2 & 3 & 4 \\
\hline 1 & Sikap hukum perkawinan & - & & & \\
\hline 2 & Kepuasan Hidup & $.678^{* *}$ & - & \\
\hline 3 & Resiliensi & $.063^{* *}$ & .017 & - & - \\
\hline 4 & Penundaan perkawinan usia dini & $.637^{* *}$ & $.877^{* *}$ & $.274^{* *}$ & \\
\hline$* * p<.05$ artinya linear & & & & \\
$P>.05$ artinya tidak linear. & & &
\end{tabular}

\section{PAPARAN HASIL}

Dari hasil uji asumsi normalitas dan linearitas diketahui bahwa uji asumsi tidak terpenuhi dengan baik, maka teknik analisis data dengan mengunakan uji non-parametrik yaitu uji korelasi spearman rho dan regresi non linear. Melalui uji korelasi spearman rho diketahui (1) terdapat hubungan positif signifikan antara sikap hukum perkawinan dengan penundaan perkawinan usia dini $\left(r=.224^{* *}, \mathrm{p}<.01\right)$, (2) terdapat hubungan positif signifikan antara sikap hukum perkawinan dengan kepuasan hidup $\left(\mathrm{r}=.155^{*}, \mathrm{p}<\right.$ .05), (3) terdapat hubungan antara sikap pemahaman hukum perkawinan dengan resiliensi ( $\left.r=.161^{*}, \mathrm{p}>.05\right)$, (4) terdapat hubungan positif signifikan antara kepuasan 
hidup dengan resiliensi $\left(r=.538^{* *}, \mathrm{p}<.01\right)$, (5) terdapat hubungan positif signifikan antara kepuasan hidup dengan penundaan perkawinan usia dini $\left(r=.296^{* *}, p<.01\right)$, serta (6) terdapat hubungan positif signifikan antara resiliensi dengan penundaan perkawinan usia dini $\left(\mathrm{r}=.350^{* *}, \mathrm{p}<.01\right)$.

Tabel 4. Hasil uji korelasi spearman rho

\begin{tabular}{llcccc}
\hline No & \multicolumn{1}{c}{ Variabel } & \multicolumn{3}{c}{$\mathrm{r}$} \\
\cline { 3 - 5 } & & 1 & 2 & 3 & 4 \\
\hline 1 & Sikap hukum perkawinan & - & & \\
\hline 2 & Kepuasan Hidup & $.155^{*}$ & - & \\
\hline 3 & Resiliensi & $.161^{*}$ & $.538^{* *}$ & - & - \\
\hline 4 & $\begin{array}{l}\text { Penundaan perkawinan usia } \\
\text { dini }\end{array}$ & $.224^{* *}$ & $.296^{* *}$ & $.350^{* *}$ & \\
\hline
\end{tabular}

$$
\text { Note: }{ }^{*} \mathrm{p}<.05 \text { (signifikan); } \quad{ }^{* *} \mathrm{p}<.01 \text { (sangat signifikan) }
$$

Selanjutnya, data penelitian juga diuji dengan regresi non-linear jenis logaritmik. Dari hasil uji regresi non-linear model logaritmik tersebut diketahui bahwa (1) sikap hukum perkawinan berperan penting bagi remaja untuk melakukan penundaan perkawinan usia dini sebesar 4,3\% ( $\left.\mathrm{r}^{2}=.043, \mathrm{t}=3063, \mathrm{p}<.05\right)$, (2) sikap hukum perkawinan berperan penting bagi remaja untuk mencapai kepuasan hidup sebesar 2,1\% $\left(r^{2}=, 021, t=2105, p<.05\right),(3)$ terdapat peran sikap hukum perkawinan bagi remaja terhadap pengembangan resiliensi sebesar 2,6\% $\left(r^{2}=.026, t=2362, p<.05\right)$, (4) terdapat peran kepuasan hidup bagi remaja untuk melakukan penundaan perkawinan usia dini sebesar 5,7 \% $\left(\mathrm{r}^{2}=.057, \mathrm{t}=3574, \mathrm{p}<.05\right)$, (5) terdapat peran resiliensi bagi remaja untuk melakukan penundaan perkawinan usia dini sebesar 11,7 \% ( $\mathrm{r}^{2}=.117, \mathrm{t}=$ 5286, $\mathrm{p}<.05$ ), (6) terdapat peran kepuasan hidup bagi remaja untuk menumbuhkembangkan resiliensi sebesar 29, $9 \%\left(\mathrm{r}^{2}=.299, \mathrm{t}=9489, \mathrm{p}<.05\right)$. Lihat tabel 6 di bawah ini.

Tabel 5. Regresi non- linear model logaritmik

\begin{tabular}{|c|c|c|c|c|c|c|c|c|c|}
\hline \multirow{2}{*}{ No } & \multirow{2}{*}{ Variabel } & \multicolumn{4}{|c|}{$r^{2}$} & \multicolumn{4}{|c|}{$\mathrm{t}$} \\
\hline & & 1 & 2 & 3 & 4 & 1 & 2 & 3 & 4 \\
\hline 1 & $\begin{array}{ll}\text { Sikap } & \text { hukum } \\
\text { perkawinan } & \end{array}$ & - & & & & - & & & \\
\hline 2 & Kepuasan Hidup & $.021^{*}$ & - & & & 2105 & - & & \\
\hline 3 & Resiliensi & $.026^{*}$ & $.299 *$ & - & & 2362 & 9489 & - & \\
\hline 4 & $\begin{array}{l}\text { Penundaan } \\
\text { perkawinan usia dini }\end{array}$ & $.043^{*}$ & $.057^{*}$ & $.117^{*}$ & - & 3063 & 3574 & 5286 & - \\
\hline
\end{tabular}

Catatan:

$* \mathrm{P}<.05$.

Untuk mengetahui apakah terdapat perbedaan antara remaja laki-laki dan perempuan dalam melakukan perkawinan usia dini, maka digunakan uji t. Hasil uji $\mathrm{t}$ diketahui bahwa rerata skor penundaan perkawinan usia dini laki-laki sebesar 4.8271 
Agoes Dariyo dkk | Pemahaman Undang-Undang Perkawinan

dengan $\mathrm{SD}=.34750$; sedangkan rerata skor penundaan perkawinan usia dini perempuan sebesar 4.7422 dengan $\mathrm{SD}=.42312$. Selanjutnya diketahui bahwa nilai $\mathrm{t}=1552, \mathrm{p}=.123, \mathrm{p}$ $>$.05. dengan demikian dapat diartikan bahwa tidak terdapat perbedaan antara laki-laki dengan remaja dalam upaya penundaan perkawinan usia dini.

Tabel 6. Hasil uji t penundaan perkawinan usia dini berdasarkan jenis kelamin

\begin{tabular}{llcccc}
\hline No & Jenis Kelamin & $\begin{array}{c}\text { M (rerata) } \\
\text { Penundaan perkawinan } \\
\text { usia dini }\end{array}$ & SD & t & $\mathrm{p}$ \\
\hline 1 & Laki-laki & 4.8271 & .34750 & 1552 & .123 \\
\hline 2 & Perempuan & 4.7422 & .42312 & & \\
\hline
\end{tabular}

Catatan: signifikansi $(\mathrm{p})>.05$

\section{PEMBAHASAN}

Hasil penelitian menunjukkan bahwa terdapat hubungan positif signifikan sikap terhadap undang-undang nomor 1 tahun 1974 tentang perkawinan dengan penundaan perkawinan usia dini pada remaja Indonesia $\left(r=.224^{* *}, \mathrm{p}<.01\right)$. Sikap terhadap hukum perkawinan ialah sikap yang tumbuh dalam diri setiap individu terkait dengan pemahaman terhadap undang-undang nomor 1 tahun 1974 tentang perkawinan. Sikap terhadap hukum perkawinan akan menumbuh-kembangkan tindakan nyata untuk menunda perkawinan usia dini. Undang-undang nomor 1 tahun 1974 tentang perkawinan menjadi landasan penting bagi setiap warga negara Indonesia untuk mengembangkan sikap, tindakan dan perilaku positif yang berkaitan dengan perkawinan. Perkawinan ialah ikatan lahir batin antara pasangan suami-istri yang dilandasi oleh keyakinan kepada Tuhan yang maha esa. Selanjutnya, pasal 28 Undang-undang Dasar 1945 menegaskan bahwa setiap orang berhak untuk melangsungkan perkawinan dengan tujuan memperoleh keturunan. Namun demikian, lebih lanjut bahwa undang-undang perkawinan menentukan seseorang wanita boleh menikah pada usia 16 tahun, sedangkan seorang laki-laki boleh menikah pada usia 19 tahun. Meskipun demikian, seseorang perlu mempersiapkan diri secara matang untuk melangsungkan pernikahannya. Karena itu, seseorang yang memiliki pemahaman dan sikap undang-undang perkawinan yang baik maka ia akan menunda pernikahan atau tidak menikah pada usia dini.

Sementara itu, melalui uji regresi non-linear logaritmik diketahui bahwa sikap undang-undang nomor 1 tahun 1974 tentang perkawinan berperan penting bagi remaja untuk menunda perkawinan usia dini sebesar 4,3\% ( $\left.\mathrm{r}^{2}=.043, \mathrm{t}=3063, \mathrm{p}<.05\right)$. Jika seorang sungguh-sungguh memahami undang-undang nomor 1 tahun 1974 tentang perkawinan dengan baik, maka ia akan memiliki sikap positif terhadap perkawinan. 
Agoes Dariyo dkk | Pemahaman Undang-Undang Perkawinan

Perkawinan itu adalah hal yang harus dijalani secara serius, sehingga setiap orang harus mampu mempersiapkan diri dengan sebaik-baiknya. Jika seseorang belum siap untuk menikah, maka sebaiknya ia tidak terburu-buru mengambil keputusan menikah pada usia muda. Karena itu, remaja yang benar-benar memahami undang-undang nomor 1 tahun 1974 tentang perkawinan, maka ia akan melakukan persiapan secara matang, sehingga ia akan menunda untuk tidak menikah pada usia dini.

Kelahiran, perkawinan dan kematian itu hanya dialami sekali saja dalam seumur hidup seseorang. Karena itu, perkawinan harus dilaksanakan dan dijalani dengan sebaikbaiknya. Sebisa mungkin, seseorang yang sudah menikah harus berpikir dan bertindak secara tepat yaitu menghindari perceraian. Ia harus mempertahankan perkawinan dengan sebaik-baiknya. Hanya kematianlah yang memisahkan pasangan suami-istri. Undangundang nomor 1 tahun 1974 tentang perkawinan memang mengatur mengenai perceraian, namun undang-undang tersebut mendorong setiap orang yang sudah menikah agar berusaha secara sungguh-sungguh untuk mempertahankan pernikahan sampai akhir hayat. Sebab, sejak awal, undang-undang ini dirancang dengan tujuan untuk mempersulit perceraian (Santoso, 2016). Jadi kalau seseorang menikah, maka ia harus berkomitmen menjaga perkawinannya demi meraih kebahagiaan dalam hidupnya. Itulah sebabnya, jika seseorang belum siap untuk menikah, sebaiknya ia jangan menikah. Ia perlu menunda pernikahan. Dengan kata lain, ia perlu menunda untuk tidak menikah pada usia dini. Dengan demikian, ia akan memanfaatkan kesempatan (waktu) untuk mempersiapkan diri dengan sebaik-baiknya demi mewujudkan masa depan yang lebih baik. Misalnya menempuh pendidikan setinggi-tingginya sampai meraih gelar sarjana, bekerja mengembangkan karir dan kemudian menikah (Goswami, 2012).

Penelitian ini menemukan bahwa sikap pemahaman hukum perkawinan mampu menumbuh-kembangkan kepuasan hidup ( $\left.\mathrm{r}=.155^{*}, \mathrm{p}<.05\right)$, sehingga seseorang berupaya untuk melakukan penundaan perkawinan usia dini $\left(r=.296^{* *}, \mathrm{p}<.01\right)$. Setiap warga negara berkewajiban untuk mempelajari, memahami dan menerapkan undangundang nomor 1 tahun 1974 tentang perkawinan. Perundang-undangan tersebut sengaja dibuat untuk mengatur tata cara perkawinan yang dilakukan oleh warga negara Indonesia. Dengan memahami perundang-undangan perkawinan, maka seseorang akan membuat persiapan-persiapan matang, agar ia siap untuk memasuki masa perkawinannya dengan baik. Perkawinan itu bukan sekedar sebagai upaya atau cara pemenuhan kebutuhan biologis, namun perkawinan itu sebagai peristiwa sakral yang menuntut seseorang untuk berani bertanggungjawab terhadap segala sesuatu yang timbul selama dirinya sudah terikat dalam pernikahan. Ikatan perkawinan harus dijaga dan dipertahankan sampai 
akhir hayat. Jangan sampai, seseorang mudah untuk bercerai di tengah jalan. Karena itu, seseorang harus mampu mencapai dan menikmati kepuasan hidup (life satisfaction) dengan baik, sebelum ia memasuki masa perkawinan.

Kepuasan hidup dapat dirasakan oleh seorang remaja jika ia mampu memenuhi berbagai aspek kebutuhan hidupnya (Eid \& Larsen, 2008). Kepuasan hidup itu memang bersifat subjektif, namun secara objektif bahwa kepuasan hidup harus dicapai dan diwujudkan oleh setiap orang. Terpenuhinya berbagai kebutuhan hidup akan menumbuhkan kepuasan dalam hidup seseorang. Bagi seorang remaja yang dapat mencapai kepuasan hidup sesuai dengan tugas-tugas perkembangannya (development tasks), maka ia akan menikmati masa remajanya dengan sebaik-baiknya (Papalia dkk., 2012; Santrock, 2019). Ia tidak akan terburu-buru untuk menikah pada usia muda. Ia harus mempersiapkan diri segala sesuatunya dengan baik. Ia menempuh pendidikan setinggi-tingginya, misalnya meraih helar kesarjanaan (Strata satu). Selanjutnya bekerja dan mencapai puncak karir. Kemudian menikah dan membentuk keluarga yang bahagia. Dengan demikian, pencapaian kepuasan hidup akan mendorong seorang remaja untuk menunda perkawinan atau tidak menikah pada usia dini. Jadi dengan pencapaian kepuasan hidup, maka seseorang tidak akan menikah pada usia dini.

Hasil ini dipertegas dengan hasil uji regresi non linear logaritmik menunjukkan bahwa kepuasan hidup berperan penting untuk penundaan perkawinan usia dini sebesar $29,9 \%\left(\mathrm{r}^{2}=.299, \mathrm{t}=9489, \mathrm{p}<.05\right)$. Artinya bahwa remaja yang memiliki kepuasan hidup berusaha untuk menikmati hidupnya dengan sebaik-baiknya, sehingga remaja tidak terburu-buru untuk menikah pada usia muda. Mereka memiliki banyak waktu untuk mengembangkan kompetensi diri melalui pendidikan demi meraih karir di masa depan yang lebih baik. Selanjutnya, kepuasan hidup berhubungan positif signifikan dengan resiliensi pada remaja $\left(\left(r=.538^{* *}, \mathrm{p}<.01\right)\right.$. Hal ini berarti remaja yang mampu mencapai kepuasan hidup, maka ia pun akan mengembangkan karakteristik ketangguhan (resiliensi) dalam hidupnya (Fenning \& Baker, 2012; Jeon \& Neppl, 2016; Schofield dkk., 2014). Adapun melalui uji regresi non linear logaritmik diketahui bahwa kepuasan hidup berperan penting untuk mengembangkan resiliensi sebesar 29, $9 \%\left(\mathrm{r}^{2}=.299, \mathrm{t}=9489, \mathrm{p}\right.$ <.05). Masih ada faktor-faktor lain sebesar 70,1\% ( $100 \%-29,9 \%=70,1 \%$ ) yang mempengaruhi tumbuh-kembangnya resiliensi dalam diri remaja, salah satu di antaranya adalah pengasuhan oangtua terhadap anak-anak dalam keluarga (Fenning \& Baker, 2012; Jeon \& Neppl, 2016; Schofield dkk., 2014).

Penelitian ini menemukan bahwa sikap pemahaman undang-undang nomor 1 tentang perkawinan memiliki hubungan positif signifikan dengan resiliensi $(r=.161, p<$ 
.05). Hal ini sesuai dengan konsep teori yang menyatakan bahwa sikap pemahaman undang-undang nomor 1 tahun 1974 tentang perkawinan akan membuat sikap tangguh (resiliensi) dalam diri seorang remaja karena seseorang mengetahui mengenai selukbeluk kehidupan perkawinan. Perkawinan itu harus dipersiapkan dengan sebaik-baiknya. Karena itu, seseorang tidak akan mengambil keputusan secara gegabah (sembarangan) dalam urusan perkawinan. Ia tidak akan mengambil keputusan yang salah. Jadi ia tidak menikah dengan sembarangan orang. Karena itu, ia pun harus memiliki persiapan matang (mature readiness) yaitu suatu persiapan yang harus dilakukan oleh seseorang dengan cara meningkatkan berbagai kompetensi kognitif, afektif maupun konatif agar ia mampu menghadapi tugas-tugas perkembangan (developmental tasks) dalam hidupnya (Berk \& Meyers, 2016). Dengan peningkatan kompetensi tersebut, maka seorang remaja akan mengembangkan resiliensi (ketangguhan) dalam menghadapi berbagai kesulitan dalam hidupnya (Brooks \& Goldstein, 2004).

Salah satu penyebab banyaknya kasus perceraian di Indonesia adalah kurangnya persiapan dalam perkawinan, terutama mereka yang menikah pada usia muda. Zubaidah (2019) menemukan bahwa mereka yang menikah muda akan mudah untuk bercerai, karena mereka tidak mampu menghadapi berbagai persoalan yang muncul selama masa perkawinan. Dari segi usia, mereka yang menikah usia muda adalah mereka yang masih tergolong remaja. Padahal remaja itu masih berada pada masa transisi yaitu masa peralihan dari masa anak-anak menuju masa dewasa yang ditandai dengan berbagai perubahan fisiologis, kognitif maupun psikososial (Papalia dkk., 2012; Santrock, 2019). Jika mereka tidak memiliki persiapan dengan baik, maka mereka pun tidak akan sanggup dalam menghadapi setiap persoalan yang kerapkali muncul dalam kehidupan perkawinan. Dengan demikian, maka persiapan harus dilakukan secara serius baik persiapan fisiologis, kognitif maupun psikososial (Papalia dkk., 2012; Santrock, 2019). Dengan persiapan yang matang, maka seseorang akan mampu mengembangkan ketangguhan (resiliensi) dalam hidupnya (Riggs \& Riggs, 2011).

Selanjutnya, hasil penelitian ini menunjukkan bahwa resiliensi berhubungan positif dengan upaya penundaan perkawinan usia dini $\left(r=.350^{* *}, \mathrm{p}<.01\right)$. Resiliensi ialah karakteristik khusus dalam kepribadian seseorang yang ditandai dengan kemampuan untuk menghadapi berbagai situasi (persoalan) yang sulit (Taylor dkk., 2010). Stanley Hall (dalam Santrock, 2019) menyebut masa remaja dihadapkan pada situasi dan kondisi yang sulit. Sebab remaja sedang menghadapi masa badai dan stress (storm \& stress) terkait dengan perubahan-perubahan aspek fisiologis, kognitif maupun psikososialnya. Secara fisiologis, seorang remaja mengalami perubahan hormonal sexual 
Agoes Dariyo dkk | Pemahaman Undang-Undang Perkawinan

sampai ia memiliki kematangan sexual yang ditandai dengan munculnya karakteristik sexual primer maupun sexual sekunder (Papalia dkk., 2012; Santrock, 2019). Secara kognitif, menurut Piaget (dalam Santrock, 2019) remaja mengalami perubahan dari tahap operasi konkrit menjadi operasi formal. Dalam konteks psikososial, menurut Erikson (dalam Papalia dkk., 2012; Santrock, 2019) seorang remaja menghadapi krisis pencarian identitas diri $><$ kebingungan identitas (identity $><$ identity difusion).

Situasi perubahan-perubahan tersebut menuntut seseorang untuk mengembangkan resiliensi dalam hidupnya (Anderson, 2018; Ponizovsky-Bergelson dkk., 2015), agar remaja mampu menghadapi berbagai perubahan aspek hidup tersebut dengan baik (Fenning \& Baker, 2012; Wadsworth \& Santiago, 2008; Zhang dkk., 2017), akibatnya, remaja akan melakukan penundaan perkawinan usia dini. Dari uji regresi non linear jenis logaritmik diketahui bahwa resiliensi berperan penting bagi remaja untuk menunda perkawinan usia dini sebesar 11,7 \% ( $\left.\mathrm{r}^{2}=.117, \mathrm{t}=5286, \mathrm{p}<.05\right)$. Masih ada faktor-faktor lain yang berperan dalam penundaan perkawinan usia dini sebesar 88,3 \% (100 \% - 11,7 $\%=88,3 \%$ ), misalnya keinginan untuk melanjutkan pendidikan tinggi, meniti dan mengembangkan karir, dan sebagainya.

\section{SIMPULAN}

Disimpulkan bahwa sikap pemahaman undang-undang nomor 1 tahun 1974 tentang perkawinan memiliki peran positif terhadap penundaan perkawinan usia dini. Selain itu, disimpulkan bahwa sikap pemahaman undang-undang nomor 1 tahun 1974 tentang perkawinan mampu menumbuh-kembangkan kepuasan hidup sehingga seserang berupaya untuk melakukan penundaan perkawinan usia dini. Demikian juga, sikap pemahaman undang-undang nomor 1 tahun 1974 tentang perkawinan memiliki peran (hubungan) dengan resiliensi, sehingga remaja berupaya untuk menunda perkawinan usia dini.

Disarankan agar setiap remaja memiliki kesdaran untuk mempelajari, memahami dan mempraktekkan undang-undang nomor 1 tahun 1974 tentang perkawinan. Karena perundang-undangan tersebut mengatur tata cara seseorang dalam menjalankan perkawinan dalam hidupnya. Untuk mewujudkan tujuan tersebut, perlu sosialisasi secara terus-menerus mengenai undang-undang nomor 1 tahun 1974 tentang perkawinan kepada remaja di Indonesia. 
Agoes Dariyo dkk | Pemahaman Undang-Undang Perkawinan

\section{UCAPAN TERIMAKASIH}

Para peneliti mengucapkan rasa terimakasih atas dukungan dana yang telah disediakan oleh Kementrian Riset dan Pendidikan Tinggi Republik Indonesia dan Direktorat Penelitian dan Pengabdian Masyarakat Universitas Tarumanagara Jakarta (2019/2020), sehingga penelitian ini dapat terlaksana dengan sebaik-baiknya.

\section{DAFTAR PUSTAKA}

Anderson, R. E. (2018). And still WE rise: Parent-child relationships, resilience, and school readiness in low-income urban Black families. Journal of Family Psychology, 32(1), 60-70. https://doi.org/10.1037/fam0000348

Ashsubli, M. (2015). Undang-Undang Perkawinan Dalam Pluralitas Hukum Agama (Judicial Review Pasal Perkawinan Beda Agama). Jurnal Cita Hukum, 3(2), 289-302. https://doi.org/10.15408/jch.v2i2.2319

Berk, L. E., \& Meyers, A. B. (2016). Infants, children, and adolescents (Eighth edition). Pearson.

Brooks, D. R., \& Goldstein, S. (2004). The Power of Resilience: Achieving Balance, Confidence, and Personal Strength in Your Life (1 edition). McGraw-Hill Education.

Djubaedah, N. (2019). Child Marriage and Zina in Indonesian Legislation In Islamic Law. Jurnal Hukum \& Pembangunan, 49(1), 202-223. https://doi.org/10.21143/jhp.vol49.no1.1917

Eid, M., \& Larsen, R. J. (2008). The science of subjective well-being. Guilford Press.

Fagan, J., \& Palkovitz, R. (2007). Unmarried, nonresident fathers' involvement with their infants: A risk and resilience perspective. Journal of Family Psychology, 21(3), 479489. https://doi.org/10.1037/0893-3200.21.3.479

Fenning, R. M., \& Baker, J. K. (2012). Mother-child interaction and resilience in children with early developmental risk. Journal of Family Psychology, 26(3), 411-420. https://doi.org/10.1037/a0028287

Goswami, B. (2012). An Investigation into the Pattern of Delayed Marriage in India.

Jeon, S., \& Neppl, T. K. (2016). Intergenerational continuity in economic hardship, parental positivity, and positive parenting: The association with child behavior. Journal of Family Psychology, 30(1), 22-32. https://doi.org/10.1037/fam0000151

Karamat, K. (2016). Perceptions on Implications of Delayed Marriage: A Case Study of Married Adults in Kuala Lumpur. International Journal of Social Science and Humanity, 6(8), 572-578. https://doi.org/10.7763/IJSSH.2016.V6.713

Köppen, K., Kreyenfeld, M., \& Trappe, H. (2018). Loose Ties? Determinants of Father-Child Contact After Separation in Germany. Journal of Marriage and Family, 80. https://doi.org/10.1111/jomf.12504 
Papalia, D. E., Olds, S. W., Feldman, R. D., Martorell, G., \& Papalia, D. E. (2012). Experience human development (12th ed). McGraw-Hill.

Ponizovsky-Bergelson, Y., Kurman, J., \& Roer-Strier, D. (2015). Adjustment enhancer or moderator? The role of resilience in postmigration filial responsibility. Journal of Family Psychology, 29(3), 438-446. https://doi.org/10.1037/fam0000080

Pranawati, R. (2018, Juli 25). Menyoal Perkawinan Anak. Kompas. https://kompas.id/baca/opini/2018/07/25/menyoal-perkawinan-anak/

Preisner, K., Neuberger, F., Posselt, L., \& Kratz, F. (2018). Motherhood, Employment, and Life Satisfaction: Trends in Germany Between 1984 and 2015. Journal of Marriage and Family, 80. https://doi.org/10.1111/jomf.12518

Riggs, S. A., \& Riggs, D. S. (2011). Risk and resilience in military families experiencing deployment: The role of the family attachment network. Journal of Family Psychology, 25(5), 675-687. https://doi.org/10.1037/a0025286

Santoso, S. (2016). Hakikat Perkawinan Menurut Undang-undang Perkawinan, Hukum Islam dan Hukum Adat. YUDISIA : Jurnal Pemikiran Hukum Dan Hukum Islam, 7(2), 412-434. https://doi.org/10.21043/yudisia.v7i2.2162

Santrock, J. W. (2019). Adolescence (Seventeenth edition). McGraw-Hill Education.

Schofield, T. J., Conger, R. D., \& Neppl, T. K. (2014). Positive parenting, beliefs about parental efficacy, and active coping: Three sources of intergenerational resilience. Journal of Family Psychology, 28(6), 973-978. https://doi.org/10.1037/fam0000024

Septiawan, A. A. (2017). Perjanjian Perkawinan pada Perkawinan Campuran dalam Kepemilikan Tanah di Indonesia. Lambung Mangkurat Law Journal, 2(1), 62-74. https://doi.org/10.32801/lamlaj.v2i1.32

Statistik, B. P. (2018). Statistik Indonesia 2018. BPS.

Taylor, Z. E., Larsen-Rife, D., Conger, R. D., Widaman, K. F., \& Cutrona, C. E. (2010). Life stress, maternal optimism, and adolescent competence in single mother, African American families. Journal of Family Psychology, 24(4), 468-477. https://doi.org/10.1037/a0019870

Wadsworth, M. E., \& Santiago, C. D. (2008). Risk and resiliency processes in ethnically diverse families in poverty. Journal of Family Psychology, 22(3), 399-410. https://doi.org/10.1037/0893-3200.22.3.399

Wardani, D. A., Mery Handayani, \& Tsia, W. T. (2018). Fakta di Balik Tingginya Angka Perceraian di Indonesia. Era Berita. https://www.era.id/read/lYUMBL-fakta-dibalik-tingginya-angka-perceraian-di-indonesia

Zhang, J., Yu, N. X., Zhou, M., \& Zhang, J. (2017). Dyadic effects of resilience on well-being in Chinese older couples: Mediating role of spousal support. Journal of Family Psychology, 31(3), 273-281. https://doi.org/10.1037/fam0000250 